\section{Australian academic research buys into Celera}

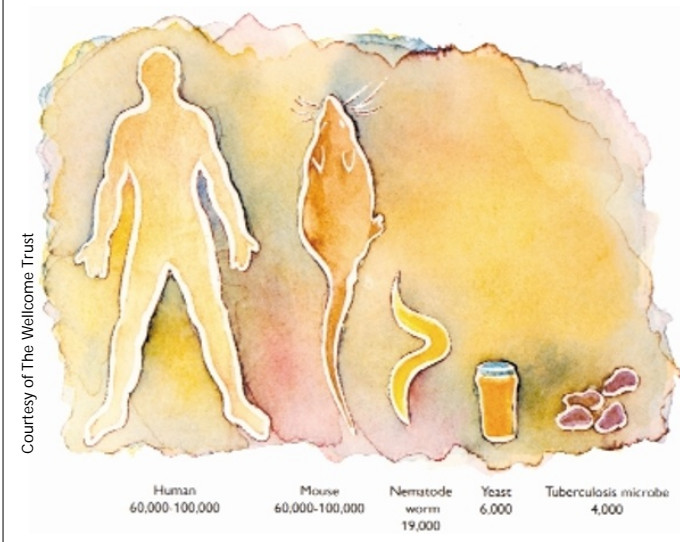

Comparison of number of genes in different organisms

In the week that the completion of the working draft of the human genome was jointly announced by political leaders in the United States and Britain, Australia became the first nation to sign a deal with the Celera Genomics Corporation to provide the country's publicly funded researchers with cut-price access to Celera databases.

Health Minister Michael Wooldridge paid tribute to Australia's National Health and Medical Research Council (NHMRC), for moving so quickly to sign the three-year agreement. Although full financial terms of the deal have not been disclosed, the NHMRC is known to have prepaid a three-year subscription, which it aims to recoup by charging an annual license fee of around US\$4,000 to principal investigators. However, the government's commitment does not yet represent any extra money for re search, as the first year of the Celera subscription will come from the NHMRC's A\$4.2 million

(US\$2.4 million) medical genomics fund.

NHMRC negotiator and deputy director of Australia's Institute for Molecular Bioscience, Brandon Wainwright sealed the deal with Celera. "This idea of a national subscription to Celera had been bubbling away for about a year but it got to boiling point obviously because Celera knew the genome announcement was coming," Wainwright told Nature Medicine.
He believes there may be some "iconic" value for the often-vilified Celera in signing up a national government.

Observers say the subscription cost is way below the commercial price offered to pharmaceutical companies and may even undercut Celera's reduced "academic" rate. NHMRC research committee chairman, Warwick Anderson, praised Celera's "public spirited" offer, which allows re searchers with existing commercial ties to fulfill those obligations and still access Celera information. Meanwhile, re searchers without commercial partners have to give Celera first appraisal of their discoveries. "We will undoubtedly add function to [Celera's] database, we're guaranteed an audience for what we find," Wainwright says, meaning that Celera will look closely at any data originating from its databases.

The subscription provides access to the Celera Discovery System (which includes tools for viewing and browsing), to the human genome database and to the mouse and annotated drosophila genomes, as well as its SN P database.

\section{Rada Rouse, Brisbane}

\title{
NIH expands graduate student training programs
}

After abandoning plans to establish its own Ph.D.-granting program (Nature Med. 5, 1098; 1999), the US National Institutes of Health (NIH) will increase the number of graduate students undertaking doctoral re search and working under university partnerships in itslaboratories. NIH will finance the research and students will be required to matriculate in a university graduate school. According to Joan P. Schwartz, Assistant Director of the NIH Office of Intramural Research, NIH will increase the number of graduate students from the current 145 to approximately 300 within five years. "I think it's going to change the atmosphere of NIH very significantly," says Schwartz.

The organization al ready has partnership programs in place with Duke, Johns Hopkins, the University of Maryland and George Washington University. Mary DeLong, who was appointed as the new director for the program on $17 \mathrm{July,} \mathrm{adminis-}$ tered a similar training program for Johns Hopkins University, is hoping to establish ties with new universities.

NIH will begin advertising its partnership programs later this year, but al ready several universities have expressed interest including Cambridge University in the UK. Some medical schools hope to start M.D./Ph.D. courses in which students would transfer to
$\mathrm{NIH}$ for their Ph.D. research. According to Schwartz, students need not necessarily be enrolled at partnership universities in order to come to NIH, but it seems likely, however, that future students will come to NIH through applications handled by DeLong's office, ending the ad hoc arrangements that have brought graduate students to $\mathrm{NIH}$ for more than 15 years.

Schwartz does not believe partnership programs will be seen as a way for NIH to compete with universities for graduate students. She says NIH is most interested in offering students opportunities in research areas in which universities may not yet be very strong, citing NIH's bioinformatics program and imaging research as examples.

$\mathrm{NIH}$ partnerships may also bring opportunities for students interested in non-degree training programs. Under discussion is are training programs in technology transfer and public health for which participants would receive a training certificate.

Tom Hollon, Bethesda

\section{Spanish oncology center under threat}

Even before his much heralded, new cancer research institute has opened for business, Spanish oncologist Mariano Barbacid has been brought to the brink of resignation due to proposed budget cuts that would leave only enough money to complete building work on the National Center of Cancer Research (CNIO) and virtually no fundsto support research.

The Instituto de Salud Carlos III-the main national biomedical research funding agency operated by the Ministry of Health (MoH) - had planned a 33\% cut in baseline funding to CNIO, and Barbacid was notified that the overall budget for 2001 would probably not include a formerly agreed increase of Ptas 1 billion (US\$5.7 million). Barbacid's resignation threat led Minister of Health Celia Villalobos to meet with Spain's Prime Minister, José Maria Aznar, to seek a solution. Barbacid has now been reassured that the promised budget will be forthcoming.

The reasons behind the proposed funding freeze are not clear. Some feel that Villalobos, appointed in May, is seeking short-term solutions to the problems of excessive healthcare expenditure on drugs. Villalobos told Nature Medicine that she is "exploring the possibility that the drug industry could become an important source of funding for CNIO." The center has already signed a major supporting agreement with Pfizer. Villalobos is also understood to be considering the introduction of an additional tax on prescription drugs to be devoted to biomedical research.

Xavier Bosch, Barcelona 